\title{
Erratum to: Progress of Physics-based Mean-field Modeling and Simulation of Steel
}

\section{Philipp Retzl ${ }^{1,3}$, Yao V. Shan', Evelyn Sobotka ${ }^{2}$, Marko Vogric ${ }^{2}$, Wenwen Wei ${ }^{2,3}$, Erwin Povoden-Karadeniz ${ }^{1,2}$, and Ernst Kozeschnik}

${ }^{1}$ Institute of Materials Science and Technology, TU Wien, Vienna, Austria ${ }^{2}$ Christian Doppler laboratory of interfaces and precipitation engineering (CDL-IPE), Institute of Materials Science and Technology, TU Wien, Vienna, Austria

${ }^{3}$ Materials Center Leoben Forschung $\mathrm{GmbH}$, Leoben, Austria

Published online February 16, 2022

\section{Erratum to:}

Berg Huettenmaenn Monatsh 2021

https://doi.org/10.1007/s00501-021-01188-x

Equation 3 should read

$A=\frac{\alpha G b M^{2}}{2 b \theta_{0}}$

Equation 5 should read

$$
C=\frac{(\alpha G b M)^{2}}{\left(\sigma_{\infty}\right)^{3}} \frac{\theta_{0} \dot{\varphi} k T}{D_{d} G b^{3}}
$$

Acknowledgements. We thank Evelyn Sobotka for spotting the typographical error in the original paper.

Open Access This article is licensed under a Creative Commons Attribution 4.0 International License, which permits use, sharing, adaptation, distribution and reproduction in any medium or format, as long as you give appropriate credit to the original author(s) and the source, provide a link to the Creative Commons licence, and indicate if changes were made. The images or other third party material in this article are included in the article's Creative Commons licence, unless indicated otherwise in a credit line to the material. If material is not included in the article's Creative Commons licence and your intended use is not permitted by statutory regulation or exceeds the permitted use, you will need to obtain permission directly from the copyright holder. To view a copy of this licence, visit http://creativecommons.org/licenses/by/4.0/.

The online version of the original article can be found under https://doi.org/10.1007/s00501-021-01188-x

E. Povoden-Karadeniz $(\varangle)$

Institute of Materials Science and Technology,

TU Wien,

Vienna, Austria

erwin.povoden-karadeniz@tuwien.ac.at
Publisher's Note. Springer Nature remains neutral with regard to jurisdictional claims in published maps and institutional affiliations. 